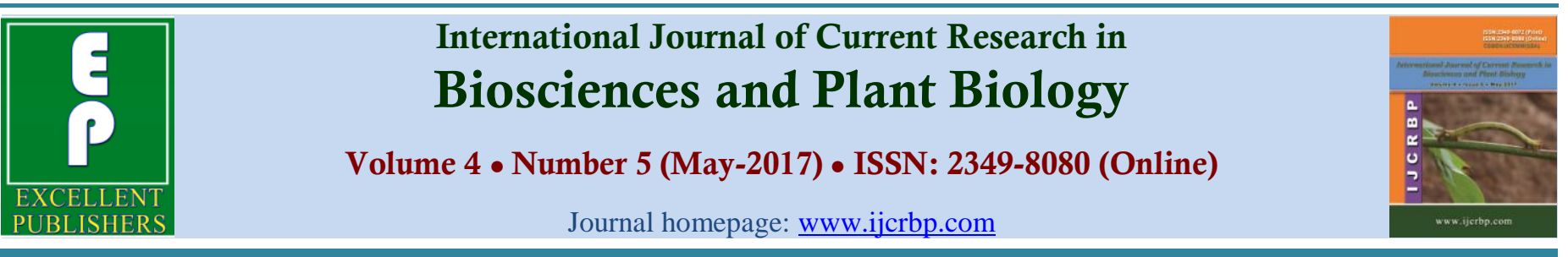

Research Note

doi: https://doi.org/10.20546/ijcrbp.2017.405.012

\title{
Notes on Indigenous Pines of India
}

\author{
R.C. Srivastava*
}

Botanical Survey of India, Kolkata, India

*Present Address: 48A/14A, MZH Road, New Katra, Allahabad-211 002, India

*Corresponding author.

\section{Abstract}

A new name viz., Pinus arunachalensis R.C.Srivast is proposed for Pinus parva which has a preoccupied name. Distinction between $P$. wallichiana, $P$. arunachalensis and $P$. ravii are given.

\section{Article Info}

Accepted: 04 May 2017

Available Online: 06 May 2017

Keywords

Indigenous pines

Pinus arunachalensis
During the course of studies on Gymnosperms of India, the author got an opportunity to conduct survey and exploration work in different parts of Arunachal Pradesh, Sikkim, J \& K, Meghalaya and Uttarakhand. During these survey and exploration tours to Metchuka area of Arunachal Pradesh state of India, the author observed an unique Pinus population in Yorlung locality beyond Metchuka which did not match with any of the known taxa. Therefore, it was described as Pinus ravii R.C.Srivast. Singh and Srivastava (2013) enlisted this species (Figs. 1 and 2).

K. C. Sahni (1989) discovered a new taxon from West Kameng area in Arunachal Pradesh which appeared to him as allied to Temperate Himalayan Pinus wallichiana described by A.B. Jackson in 1938 and hence he described it as a variety viz., P. wallichiana var. parva
K.C.Shani in (1989) which is native to Tawang and West Kameng districts of Arunachal Pradesh.
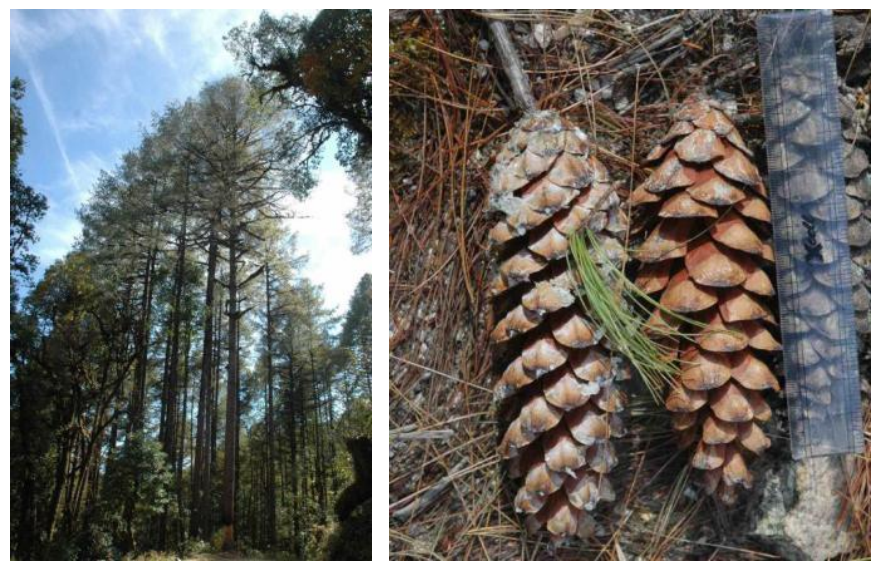

Fig. 1: Pinus ravii: Habit. Fig. 2: $P$. ravii: Female cone and needles. 
Srivastava (2013) based on his field observations of the live population in Himalayan region elevated Pinus wallichiana var. parva K.C.Sahni, to species viz., Pinus parva (K.C.Sahni) R.C.Srivast. In the "World Checklist of Selected Plant families", Pinus wallichiana var. parva K.C.Sahni is treated as synonym and Pinus parva (K.C.Sahni) R.C.Srivast., and is cited as accepted name while Pinus wallichiana subsp. parva (K.C.Sahni) Silba (2009) is cited as Homotypic synonym. But the name Pinus parva is not available as it was already used by Ammosov (1937) for a fossil species. Hence, a new name viz., Pinus arunachalensis R.C.Srivast, is proposed to Pinus parva (K.C. Sahni). R.C.Srivast.
Pinus arunachalensis R.C.Srivastava, Nomen Nova

Pinus parva (K.C. Sahni) R.C.Srivast. Indian J. Pl. Sci. 2(1): 40-42. 2013, non Ammosov 1937 fossil name. Pinus wallichiana var. parva K.C.Sahni Indian J. Forestry 12 (1): 40. 1989. Pinus wallichiana subsp. parva (K.C.Sahni) Silba, J. Int. Conf. Preserv. Soc. 16: 36. 2009.

\section{Etymology}

The specific epithet 'arunachalensis' is based on the name of the province (Arunachal Pradesh) of the type locality of this taxon.

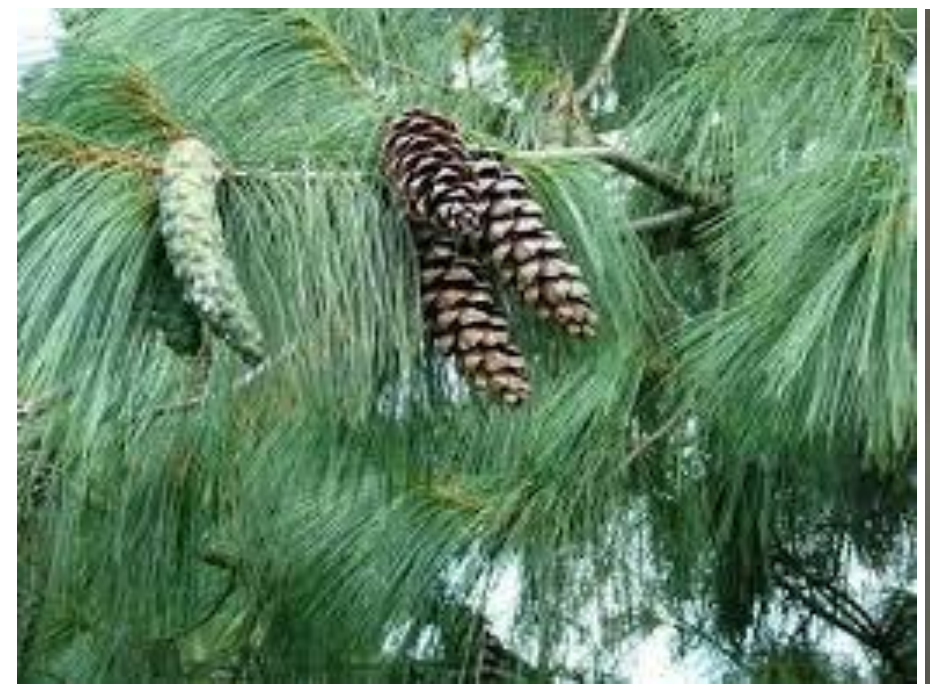

Fig. 3: P. wallichiana

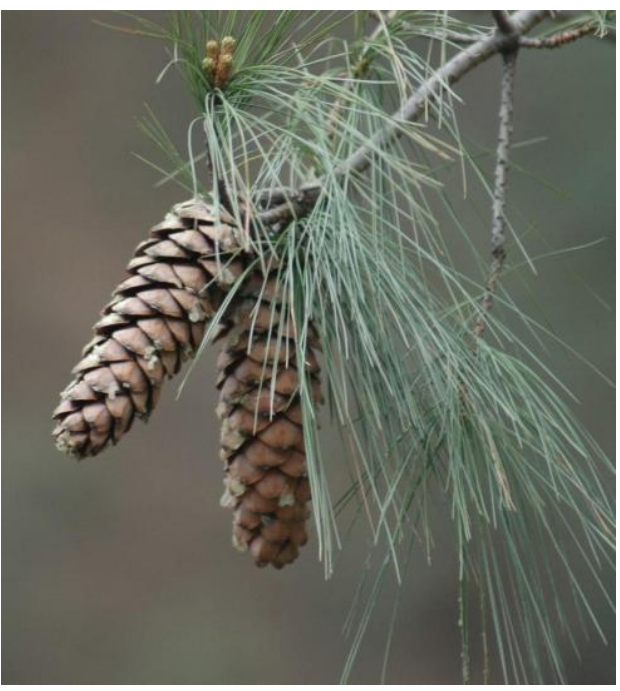

Fig. 4: P. arunachalensis R.C.Srivast.
Above 3 species can easily be distinguished from each other by their canopy, needles and female cones. Pinus wallichiana- the common blue pine (Fig. 3), has bluish blazé; its needles are blue, longest (15-30 cm long) of the three species and the female cones are blue, quite compact cylindrical and tapering at lower end, mostly curved and almost as long as needles; if grown at lower altitudes the tree becomes spreading and the canopy is changed. In Pinus arunachalensis R.C.Srivast. (Fig. 4) which is native to Tawang and West Kameng areas of Arunachal Pradesh, almost all parts are smaller than $P$. wallichiana but bigger than $P$. ravii R.C. Srivast. (Figs. 1 and 2). Blaze of $P$. ravii is grayish white and the architecture (Fig. 1) of the tree is quite different from $P$. wallichiana. Pinus arunachalensis and $P$. ravii are not yet recorded from Western Himalaya.

\section{Conflict of interest statement}

Author declares that there is no conflict of interest.

\section{Acknowledgement}

Author is sincerely grateful to Dr. Rafaël, Govaerts, Royal Botanic Gardens, Kew (UK), for his valuable comments and guidance.

\section{References}

Ammosov, I.I., 1937. Iskopaemaja mikroflora iz uglej Bukachachinskogo mestorozhdenija Zabajkal'ja, Izvestiya Tomskogo industrial'nogo instituta. 58(3), 39. 
Jackson, A.B., 1938: Kew Bull. 85.1938.

Sahni, K.C., 1990. Gymnosperms of India and Adjacent Countries. Bisen Singh and Mahendra Pal Singh, Dehradun, India.

Singh, N.P., Srivastava, R. C., 2013. Gymnosperms of India: A Checklist. Botanical Survey of India, Kolkata, India.

\section{Websites:}

https://goo.gl/images/4yhI7h (P. wallichiana)

http://www.dmkert.hu/tovabbikepek/Pinuswallichiana22 .jpg (P. wallichiana)

\section{How to cite this article:}

Srivastava, R. C., 2017. Notes on indigenous pines of India. Int. J. Curr. Res. Biosci. Plant Biol. 4(5), 85-87. doi: https://doi.org/10.20546/ijcrbp.2017.405.012 